\title{
An unusual association of corpus callosum agenesis in a patient with acromegaly
}

\author{
Sambit Das, ${ }^{1}$ Anil Bhansali, ${ }^{1}$ Pinaki Dutta, ${ }^{2}$ Niranjan Khandelwal,${ }^{2}$ Vimal Upreti, ${ }^{2}$ R Santosh ${ }^{2}$ \\ ${ }^{1}$ Department of Endocrinology, PGIMER, Chandigarh, India \\ ${ }^{2}$ PGIMER, Chandigarh, India
}

Correspondence to Anil Bhansali, anilbhansali_endocrine@rediffmail.com

\section{DESCRIPTION}

Midline developmental abnormalities are usually associated with isolated growth hormone deficiency or multiple pituitary hormone deficiencies due to pituitary transcription factor defects. ${ }^{1}$ We describe a case with midline defects presenting as corpus callosum agenesis and acromegaly. A 39-year-old male presented with congestive cardiac failure with overt clinical features of acromegaly. He was a graduate, was mentally normal and had no visible morphological abnormality. On evaluation, serum growth hormone after $75 \mathrm{~g}$ of anhydrous glucose load was non-suppressible (12 $\mu \mathrm{g} / \mathrm{l}$, normal $<1 \mu \mathrm{g} / \mathrm{l})$ and insulin-like growth factor-1 was elevated (900 $\mu \mathrm{g} / \mathrm{l}$, normal 114-49 $\mu \mathrm{g} / \mathrm{l})$. He was hypothyroid, hypocortisolic and hypogonadal and was on replacement therapies. MRI of the head showed a pituitary macroadenoma $(2 \times 1.5 \times 1 \mathrm{~cm})$ with left parasellar extension and subacute apoplexy and incidental findings of complete agenesis of corpus callosum (ACC) and right cerebral hemiatrophy (figure 1 and 2). His karyotype was 46, XY with no chromosomal abnormalities. The patient underwent transsphenoidal surgery and was cured.

The corpus callosum is a band of white matter structure connecting the cerebral hemispheres medially. It develops from the lamina reuniens in the telencephalon. ACC is an

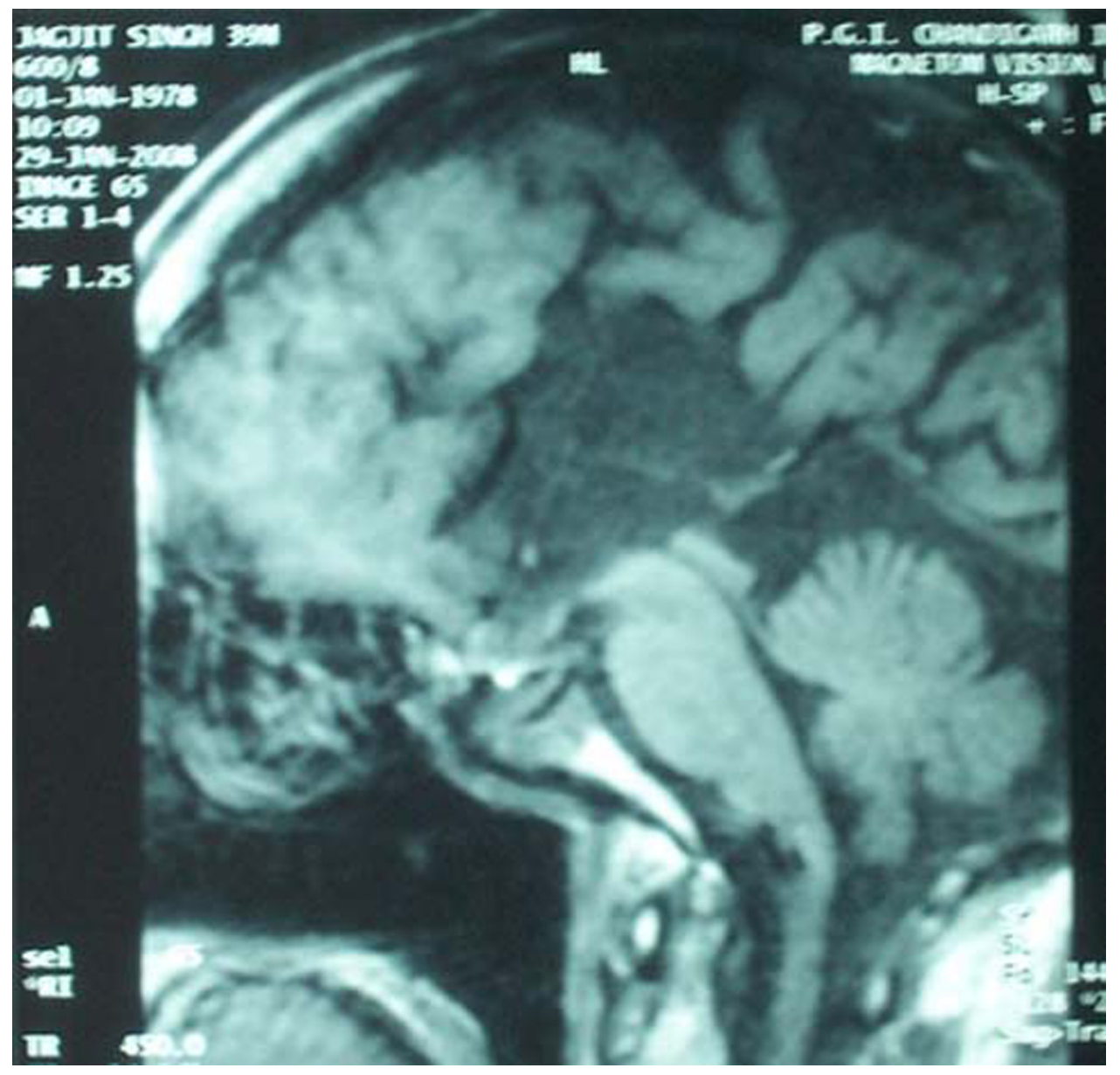

Figure 1 MRI sagittal section of the brain showing complete corpus callosum agenesis. 


\section{BMJ Case Reports}

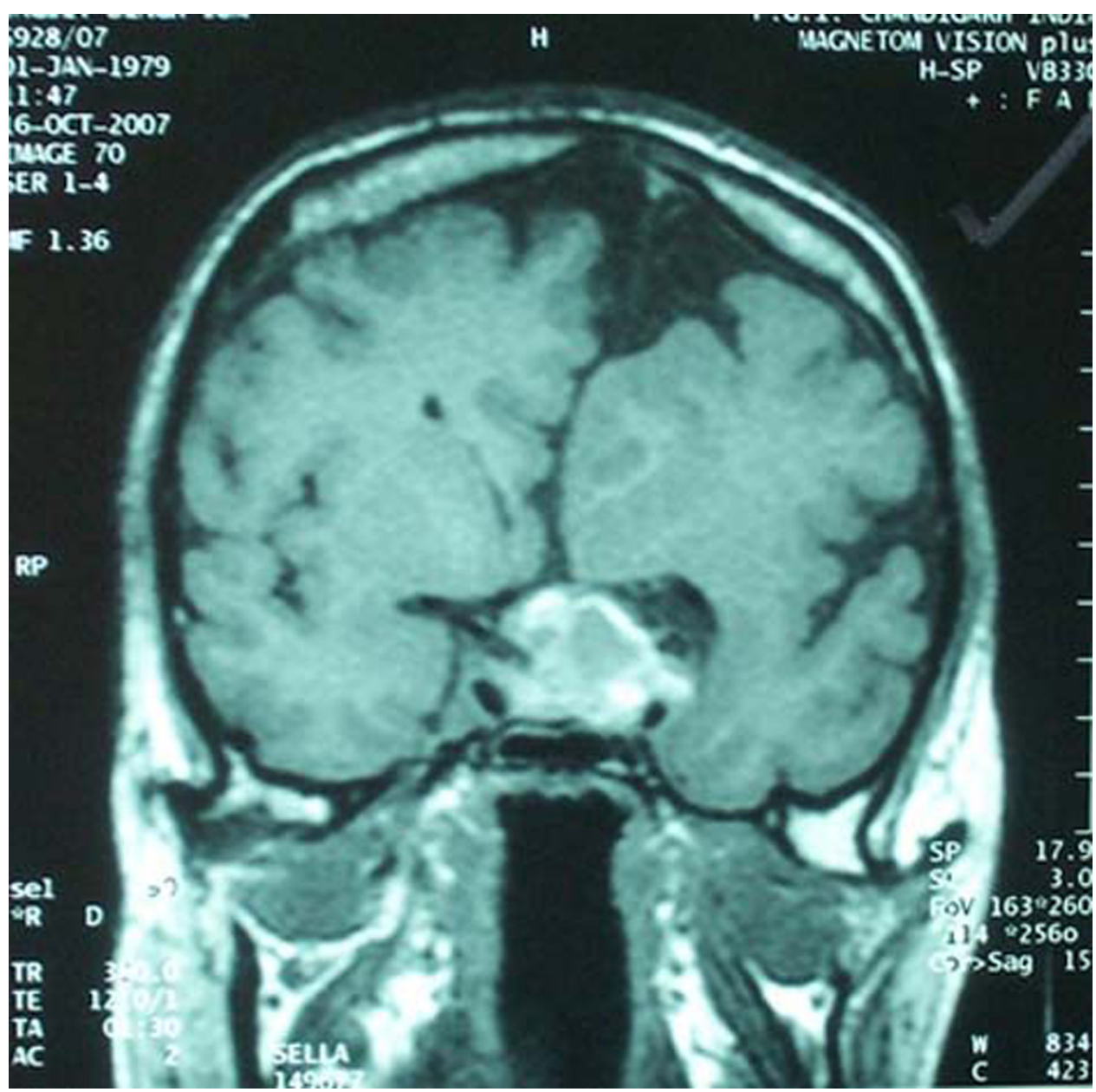

Figure 2 Coronal section of MRI of the brain and sella showing a pituitary macroadenoma with left cavernous sinus extension and subacute apoplexy with corpus callosum agenesis and right cerebral hemiatrophy.

anomaly that may occur in isolation or in association with Dandy-Walker cyst, congenital hydrocephalus, ArnoldChiari malformation, holoporencephaly, polymicrogyria and sometimes with chromosomal anomalies such as trisomy 18,13 and $8 .^{2}$ Signs and symptoms of ACC vary from asymptomatic presentation as seen in our case, to vision impairment, hypotonia, delayed motor milestones, learning disabilities and, rarely, seizures and spasticity. ${ }^{3}$ This seems to be a chance association and extremely rare in acromegaly.
Competing interests None.

Patient consent Obtained.

\section{REFERENCES}

1. Cameron FJ, Khadilkar WV, Stanhope R. Pituitary dysfunction, morbidity and mortality with congenital midline malformation of the cerebrum. Eur J Pediatr 1999;158:97-102.

2. Schell-Apacik CC, Wagner K, Bihler M, et al. Agenesis and dysgenesis of the corpus callosum: clinical, genetic and neuroimaging findings in a series of 41 patients. Am J Med Genet A 2008;146A:2501-11.

3. Marszal E, Jamroz E, Pilch J, et al. Agenesis of corpus callosum: clinical description and etiology. J Child Neurol 2000;15:401-5. 


\section{BMJ Case Reports}

This pdf has been created automatically from the final edited text and images.

Copyright 2010 BMJ Publishing Group. All rights reserved. For permission to reuse any of this content visit http://group.bmj.com/group/rights-licensing/permissions.

BMJ Case Report Fellows may re-use this article for personal use and teaching without any further permission.

Please cite this article as follows (you will need to access the article online to obtain the date of publication).

Das S, Bhansali A, Dutta P, Khandelwal N, Upreti V, Santosh R. An unusual association of corpus callosum agenesis in a patient with acromegaly. BMJ Case Reports 2010;10.1136/bcr.01.2010.2625, date of publication

Become a Fellow of BMJ Case Reports today and you can:

Submit as many cases as you like

- Enjoy fast sympathetic peer review and rapid publication of accepted articles

- Access all the published articles

- Re-use any of the published material for personal use and teaching without further permission

For information on Institutional Fellowships contact consortiasales@bmjgroup.com

Visit casereports.bmj.com for more articles like this and to become a Fellow 